\title{
Effect of Conflict Management Strategies on the Relationship between Corporate Governance and Organizational Performance in State Corporations in Kenya
}

\author{
Jenifer W. Muriuki, Thomas Cheruiyot, Joyce Komen \\ School of Business, Moi University, Eldoret, Kenya \\ Email address: \\ kiraundi@yahoo.com (J. W. Muriuki) \\ To cite this article: \\ Jenifer W. Muriuki, Thomas Cheruiyot, Joyce Komen. Effect of Conflict Management Strategies on the Relationship Between Corporate \\ Governance and Organizational Performance in State Corporations in Kenya. Science Journal of Business and Management. \\ Vol. 5, No. 4, 2017, pp. 158-168. doi: 10.11648/j.sjbm.20170504.14
}

Received: May 12, 2017; Accepted: May 20, 2017; Published: July 12, 2017

\begin{abstract}
This study seeks to explore the influence of corporate governance on organizational performance of state corporations moderated by Board Conflict management Strategies in Kenya. A survey design was used to arrive at the expected outcomes in this study. Data was collected from 375 respondents with a response rate of $82.4 \%$. Descriptive and inferential statistics were computed using statistical package of social sciences. Linear regression model was used to determine the relationship between corporate governance and organizational performance. The study revealed that board conflict management strategies are key factor in resolving conflict within the board and in the State Corporation. Once a conflict is resolved, the study found that organization performance changes by $7 \%$. The researcher recommends application of Arbitration, Negotiation and Mediation strategies in resolving a conflict in the state corporation for the effective and efficient service delivery.
\end{abstract}

Keywords: State Corporation, Organization Performance, Board, Customer Satisfaction, Corporate Governance

\section{Introduction}

The Kenya Government in 2002 issued its corporate governance principles assigning new roles and imposing a structure of the board of directors, with a view to improving performance of the state corporations. However, Board conflicts have been witnessed in many parastatals, resulting to disintegration due to nonperformance. The role of the board in Kenya state Corporations has been of little value mainly due to lack of professionalism as board member selection criteria (Forbes \& Milliken, 1999). The Board of Directors acts as intermediary between the principals and their agents and is charged with four main responsibilities namely leadership, Stewardship, monitoring and controlling managerial discretion (Jensen and Ruback 1983). Empirical evidence suggests that public firms are highly inefficient in comparison to private ones (Meggison et al 1994), even in pursuing public interests. There are several reasons for such observed poor performance of state owned firms. According to Shleifer and Vishney (1994), state owned firms are governed by bureaucrats or politicians that have extremely concentrated control rights without significant cash flow rights since all the profits generated by the firms are channeled to the government Treasury to finance National budget. This is aggregated by political goals of bureaucrats that often deviate from prudent business principles (Repei 2000). Such enormous inefficiency of state firms has precipitated a wave of governance transformation through privatization of state firms. Poor performance of government firms has also been attributed to the tendency of these firms not to strictly adhere to government statutory requirements and regulations (Huse 2007). Political manipulation and poor human resources practices are other factors that have been blamed for the general poor performance. Effective board performance is driven by the extent to which corporate directors bring relevant knowledge into the boardrooms. An important prerequisite however is that this knowledge must be actively utilized.(Forbes and Milliken 1999). The competences and behaviors of the board chairperson are critical in order to unleash a board's value -creating potential. 
However it is important to note that boards are composed of directors with different backgrounds, ways of thinking and self interests that they result to conflicts (Forbes and Miliken 1999), and Huse (2007). A major conflict within the boardroom is between the CEO who acts as a secretary and the board directors. The CEOs have incentives to "capture" board to ensure them their jobs and other benefits, but two processes that feature prominently and understood to have opposite effect on the quality of the boards of the directors strategic decisions are cognitive and affective conflicts. However, no known parastatal in Kenya seems to have put in place sound conflict management strategies to address conflicts that have been witnessed in many parastatals and that have negatively affected their performance almost to zero level. This is the knowledge gap that this study intends to address by focusing on conflict resolution strategies that addresses the many typologies of conflicts in the boardrooms that inhibit rather than promote organizational performance. The purpose of this study was to examine the relationship between corporate governance and organizational performance of the state corporations moderated by Board Conflict Management Strategies.

\section{Literature Review}

\subsection{Concept of Corporate Governance}

Corporate governance is seen as the process and structure used to direct and manage the business affairs of the company towards enhancing business prosperity and corporate accountability with the ultimate objective of realizing long-term shareholder value, whilst taking into account the interest of other stakeholders. Claesses et al. (2002) maintain that better corporate frameworks benefit firms through greater access to financing, lower cost of capital, better performance and more favorable treatment of all stakeholders. While there exist numerous approaches to assess the quality of the legal and institutional framework of countries (Kaufmann et al. 2003), investors have shown a growing demand for a global benchmark of good corporate behavior, which can help create shareholder value regardless of the particular system (Gompers et al. 2003). Corporate governance processes matter to workers because they shape the creation of wealth and its distribution into different pockets; the portfolios of pensioners and retirees, the claims of the rich and the poor rewards to entrepreneurial initiative; the incentives firms have to invest in their labor force and social welfare, health, and retirement plans (Gourevitch and Shinn, 2005.) It is believed that good governance generates investor goodwill and confidence. Again, poorly governed firms are expected to be less profitable. Claessens et al (2003) also posit that better corporate framework benefits firms through greater access to financing, lower cost of capital, better performance and more favourable treatment of all stakeholders. They argue that weak corporate governance does not only lead to poor firm performance and risky financing patterns, but are also conducive for macroeconomic crises like the 1997 East Asia crisis. Other researchers contend that good corporate governance is important for increasing investor confidence and market liquidity (Donaldson, 2003).

Corporate governance is not just about board structure and interests alignments for its own end. It is very much about perceived benefits in terms of attraction of capital and its retention. For corporations it could well mean enhanced market capitalization. An international corporate governance survey showed that investors are prepared to pay more for corporations with more effective governance structures and practices. This resulted in lower share premiums for Asian, Latin American and other emerging economies; a comparatively higher premium for those in continental Europe where there are still pressures for better disclosure of information to shareholders; and an even higher premium for those in the UK and US capital markets where information disclosure to shareholders is enhanced either through strict securities laws or codes of best practices. Financial information disclosure is crucial not only to ensure transparency and accountability, but more importantly the sustenance of market liquidity to provide a workable environment for corporate divestment, takeover and merger activities. Contrary to this, the corporate and capital market frameworks are geared towards greater focus on transparency, accountability and enforcement issues. Solomon et al (2003) emphasized the importance of good Governance and claim that corporate Governance involves a set of relationships between a state owned enterprises management, its Board, its shareholders and other stakeholders with increasingly acceptance of good corporate Governance in developing countries, the state owned enterprise sector is an integral part of socio-economic activity. Most state corporations were established to fulfill the social objectives of the state rather than to maximize profits. However, rising stakeholder expectations have forced Governments in many countries to reform the corporate governance systems of state owned enterprises with exceptions of improving their operations to reduce deficits and to make them strategic tools in gaining national competitiveness (Dockey and Herbert, 2000).

The transparency, accountability and probity of organizations make them acceptable as caring, responsible, honest and legitimate wealth creating organs of society. The enhanced legitimacy, responsibility and responsiveness of business enterprises within the economy and improved relationships with their various stakeholders comprising of shareholders, managers, employees, customers, suppliers, host communities, providers of finance and the environment enhance their market standing, image and reputation (Gourevitch and Shinn, 2005). However, relevant data from empirical studies are still few and far between. In 2003, the Kenya Government made a commitment to reintroduce Performance Contract (PCs) as a Management tool to ensure accountability for results and transparency in the management of public resources. This policy commitment is continued in the Economic recovery established the performance contracts steering committee to spearhead the 
introduction and implementation of the PCs in August 2003 and December 2004. A Pilot group of sixteen state corporations signed PCs on $1^{\text {st }}$ July 2005, and the others immediately joined in. The type of PCs adopted in Kenya is the signaling system where the management use of resources is being evaluated (DPM, 2005).

\subsection{Theoretical Framework for Corporate Governance}

The main theories reviewed in this section are the Agency theory, stakeholders' theory, stewardship theory, signaling theory and the resource dependence theory.

\subsubsection{Agency Theory}

Chen, Chen and Wei, (2004) showed that the effect of good corporate governance on expected returns is more profound for firms with higher free cash but poor investment opportunities and for firms with lower insider ownership, consistent with agency costs of free flows as proposed by Jensen and Meckling (1976) Agency theory. The principalagent model starts from an assumption that the social purpose of corporations is to maximize shareholders' wealth (Coelho et al., 2003). The principal-agent model regards the central problem of corporate governance as self-interested managerial behavior in a universal principal-agent relationship. Agency problems arise when the agent does not share the principal's objectives. Furthermore, the separation of ownership and control increases the power of professional managers and leaves them free to pursue their own aims and serve their own interests at the expense of shareholders. Historically, definitions of corporate governance also took into consideration the relationship between the shareholder and the company, as per "Agency Theory", i.e. directoragents acting on behalf of shareholder-principles in overseeing self-serving behaviors of management. However, broader definitions of corporate governance are now attracting greater attention (Solomon and Solomon, 2004). Indeed, effective corporate governance is currently understood as involving a wide number of participants. The primary participants are Management, shareholders and the boards of directors, but other key players whose interests are affected by the corporation are employees, suppliers, customers, partners and the general community. Therefore, corporate governance, understood in these broadening social contexts, ensures that the board of directors is accountable not only to shareholders but also to non-shareholder stakeholders, including those who have a vested interest in seeing that the corporation is well governed. Some corporate governance scholars (Carter and Lorsch, 2004; Leblanc and Gillies (2005) also argue that at the heart of good corporate governance is not board structure (which receives a lot of attention in the current regulations), but instead board process especially consideration of how board members work together as a group and the competencies and behaviors both at the board level and the level of individual directors (Deetz 2006). In such a principal-agent relationship, there is always "inherent potential for conflicts within a firm because the economic incentives faced by the agents are often different from those faced by the principals" (ISDA, 2002). According to ISDA (2002), all companies are exposed to agency problems, and to some extent develop action plans to deal with them. These include establishing such measures as: "controls on the actions of agents, monitoring the actions of agents, financial incentives to encourage agents to act in the interest of the principals, and separation of risk taking functions from control functions" (ISDA, 2002).

\subsubsection{Stewardship Theory}

The stewardship theory, on the other hand suggests that managerial opportunism is not relevant. The aim of management is to maximize the firm's performance since that speaks of the success and achievements of Management. Donaldson (2006) argue that managerial opportunism does not exist because the manager's main aspiration is "to do a good job, to be a good steward of corporate assets". This clearly replaces the lack of trust to which the agency theory refers with the respect for authority and inclination to ethical behavior. The resource dependence approach, developed by Pfeffer and Salancik (2008), emphasizes that non-executive directors enhance the ability of a firm to protect itself against the external environment, reduce uncertainty, or co-opt resources that increase the firm's ability to raise funds or increase its status and recognition. Firms attempt to reduce the uncertainty of outside influences to ensure the availability of resources necessary to their survival and development. The board is hence seen as one of a number of instruments that may facilitate access to resources critical to company success, and this applies to Kenyan State Corporations.

\subsubsection{Stakeholder Theory}

Similarly, the stakeholder approach also considers the provision of resources as a central role of board members. The main resource stakeholder proponents refer to is consensus. According to this view, the board should comprise representatives of all parties that are critical to a company's success. This will result in the firm's ability to build consensus among all critical stakeholders (Analytica 1992). The board of directors is hence seen as the place where conflicting interests are mediated, and where the necessary cohesion is created. The stakeholder theory argues about the importance of a firm paying special attention to the various stakeholder groups in addition to the traditional attention given to investors (Gibson, 2000). These various groups of stakeholders, which include customers, suppliers, employees, the local community and shareholders, are deemed to also have a stake in the business of a firm. The representation of all stakeholder groups on boards is therefore necessary for effective Corporate Governance Warning 1973, Clackson 1994) NSSF, NHIF State Corporations in Kenya are examples. Three premises underpin stakeholder theory, firstly, organizations have stakeholder groups that affect and are affected by them, secondly, these interactions impact on specific stakeholders and the organization, and thirdly, perspectives of salient stakeholders affect the viability of strategic options (Haberberg and Rieple, 2001). Applications of stakeholder 
theory can be functionalist or radical, but it is the scope of the radical perspective to provide a more balanced, realistic and ethical view of organizational relationships (Friedman and Miles, 2002) and to pave the way for an era of socially responsible governance that is the focus of this study.

\subsection{The Board of Directors Influence on Corporate Performance}

Boards of directors are a crucial part of the corporate structure. They are the link between the people who provide capital (the shareholders) and the people who use that capital to create value (the managers) Duffon and Jackson (1987). This means that boards are the overlap between the small, powerful group that runs the company and a huge, diffuse, and relatively powerless group that simply wishes to see the company run well (Business Roundtable, 2005). The single major challenge addressed by corporate governance is how to grant managers enormous discretionary power over the conduct of the business while holding them accountable for the use of that power (Turnbull 1995). A company's owners may number in the tens of thousands, diffused worldwide (Mace 1986).

Therefore shareholders are granted the right to elect representatives to oversee the management of the company on their behalf (Karfer 1992). Directors are representatives of owners (or, in closely held companies, the owners themselves), whose purpose under law is to safeguard the assets of the corporation (Monks and Minow, 2004). In performing its oversight function, the board is entitled to rely on the advice, reports and opinions of management, counsel, auditors and expert advisers (Judge Reinstart 1997). Given the board's oversight role, shareholders and other constituencies can reasonably expect that directors will exercise vigorous and diligent oversight of a corporation's affairs. The board's oversight function carries with it a number of specific responsibilities in addition to that of selecting and overseeing the CEO (Jesen and Meckling 1997) These responsibilities include: Planning for management development and succession. Understanding, reviewing and monitoring the implementation of the corporation's strategic plans, Understanding and approving annual operating plans and budgets, focusing on the integrity and clarity of the corporation's financial statements and financial reporting. Advising management on significant issues facing the corporation, Reviewing and approving significant corporate actions, Reviewing management's plans for business resiliency, Nominating directors and committee members and overseeing effective corporate governance as well as legal and ethical Compliance Miliken 1999). i.e. avoidance of static and abstract categorizations, and attention to multiple interactions. This framework involves: measures of cultural dispersion, the degree to which cultural characteristics are dispersed throughout an organization Sociologically, psychologically, historically and art factually; measures of cultural potency the power of the culture itself to influence behavior; studies of 'how specific culturally conditioned processes contribute to outcomes'; and the recognition of multiple, mutually casual interactions (Barney et al 1996). Hardly surprisingly, he notes that 'if it all sounds complex, it is unavoidably so', but believes that his framework 'reflects the richness of culture performance relationships' (Scott 1998).

\subsection{The Key Variables Under Study}

\subsubsection{Board Chair Leadership}

The Board chairperson in Kenyan state corporations is generally leader for the Board members at the Board meetings. The Board of directors therefore has few face-toface meeting and after time constraints as in most cases members with permanent secretary serves in other Board as pointed out by Forbes and Milliken (1999). These specific situations make Board vulnerable to induction difficulties and put special demand on how to lead the team in order to carry on its work in efficient and effective manner. Consequently, the quality of that person, leadership in the Boardroom could be predicted to have a major impact on the effectiveness within which Board members perform their duties. The Board chairperson is responsible for decision making and are in implementation or leadership and capabilities or the chairperson affect the work of the Board of directors (Cadbury 2002, Leblac 2005). The Board chairperson should contribute to a cohesive culture should be among the Board members. (Forbes and Milliken 1999) stimulate creative processes in the Boardrooms. The Board chairperson should encourage a critical and questioning attitude in the Boardroom. (Minichill and scheming 2005). It is therefore doubtful that a strong, engaged Board will have a weak chairperson or that an ineffective Board will have a strong and competent leader as the Board chairperson (Leblanc 2005). This will contribute positively to achieving performance and Transparency in the Boardroom and the organization with the Kenya Revenue Authority (KRA).

\subsubsection{Board Team Production Culture}

The team production approach emphasizes that Board should represent stakeholders that add value assume unique task and posses strategic information relevant for firm operation (Englander 2005). The font input are expert firm knowledge in strategic decision making process is key to creating competitive advantage. The team production perspective consequently stands for shareholders supremacy model where Board is permanently seen as representative of shareholders interests. Activity shareholders supremacy model there is a need for independent Board members while a team production approach suggests that independent director may list damaging the long team creation of value (Kanfman 2005). The team productive culture can be characterized by cohesiveness, creativity, openness and generosity criticality and involvement and preparedness (Forbes and Muliken 1999, Huse Scbmony 2005, Stiles and Taylor 2002). As a team leader, the Board chairperson should be able to build consensus among Board members (Huse 2007). To create a team production culture the Board chairperson must the ability to motivate and use the 
conferences from each Board member and an open and trustworthy leadership style or the chair effects Board processes and customer because the Board is a social system containing a mix or personalized and relationship (Cascio 2004, Furral Furr 2005). In Board team production culture consideration i.e. given to the dimensions namely, cohesiveness creativity, openness and generosity, criticality preparedness and involvement.

\subsubsection{Board Strategic Involvement}

A Constructive team production culture can strengthen the roles and contributions of each team member and enhance Board ability to be involved in shaping the organization mission and strategies (Kaufman and Englander 2005). A better understanding of the role and contribution by each team member can moreover facilitate active involvement and commitment by all the members of the Board (Demb and Neubauer 1992). Thus, A constructive team production culture may support the effectiveness of the Board as a whole and bring out the potential that is in the Board as a team (Forbes and miliken 1999). Board effectiveness is about how actual Board task performance meets Board task expectations (Huse 2005). Effective Boards add value and contribute to the direction and performance of the Organization by their involvement in strategic decision making (forbes and Milliken 1999, judge and zeithamil 1992). Involvement in initiating and formulating strategic decisions means shaping the context, content and conduct of strategies and not only ratifying and monitoring strategic decisions (Mcnutty and Pettigrew 1999). This enables the protection of stakeholders interests through problem identification and problem definitions in the early stages of the strategic decision-making process (Rindova 1999). Board involvement in strategic decisionmaking however requires actions engagement by the members of the board. The Board strategic involvement in the four stages in the strategy namely initiation, ratification, implementation and control.

\subsubsection{CEO-Board Chair Collaboration}

The CEO-Board chair friendship ties imply trust or expectation of personal loyalty (Krackhardt 1992) Similarly Segal 1979 noted that certain social obligations are normatively part of the friendship. This friendship relations is governed by communal norms whereby individuals are obliged to care for each other's welfare rather than exchanged-based with reciprocation of benefits norms (Clark and Mills 1982). Thus, friendship ties between CEO and outside directors should increase the boards' loyalty to the CEO. (John and Shaw 1997). Although the independent Board Model suggests that such loyalty should diminish board-monitoring activity, the collaboration model agrees that perceived friendship ties may increase CEOs adviceseeking behavior by enhancing his or her trust in the boards supports while also increasing the board's perceived social obligation to provide assistance. Further CEOS financial incentives may enhance the benefits of friendship ties with the directors. From an Agency Perspective, incentive alignment motivates a CEO to use corporate resources to the advantage of shareholders (Jesen and Murphy 1990).

\subsubsection{Board of Directors' Knowledge and Skills}

Effective board performance is driven by the extent to which the directors bring relevant knowledge to the boardroom and this knowledge and skills must be actively used to function effectively (jackson 1992). Knowledge and skills are characterized in two main dimensions namely functional area knowledge and skills and firm- specific knowledge and skills. Functional areas include law, accounting and marketing that aid in information gathering and problem solving (Ancona and Cardwell 1988). Firm specific knowledge and skills refer to detailed information about the organization an intimate understanding of its operations and internal management issues and to deal effectively with strategic issues (Nonaka 1994). They should be able to understand cause-effect relationship involving the needs of customers, sources of risks to the organizations and impediments to output quality (Mc Greth 1995).

\subsection{Definition of Conflict in Decision-Making Process}

Many researchers have sought to explain the multidimensionality of conflict and its paradoxical effects on decision-making (Amason 1996; Jehn, 1995). The primary prescription emerging from this work has been addressed to teams in order to identify the benefit of cognitive (task) conflict while simultaneously avoiding the cost of effective (emotional) conflicts. For some time, researchers have sought to explain the paradoxical effects of conflicts on decisionmaking (Amason 1996; Jehn, 1995). As a result, two-fold dimensions of the conflict, both cognitive and affective, have come forth. Cognitive conflict occur when teams discuss and debate various preferable and opinions about their tasks. Such debates promote better decision-making by forcing teams to accommodate and syntheses multiple points of view (Schweiger et., 1989). Affective conflict, on other hand, occurs when team members from the work and issues at hand (Jehn, 1994, 1995; Simons and Peterson, 2000). In lights of these dimensions, and effects associated with them, researchers have suggested that decision-making improves as teams are able to gain the benefits of Cognitive conflict, while avoiding the cost effective conflict (Amason and Sapienza, 1997, 1995; Simons and Peterson, 200). Cognitive conflict is a tasks-oriented conflict and arises from disagreement in judgment over the content of the tasks being performed, including differences in viewpoints, ideas and opinions. What seems important is that conflicts among directors arise from social ties and business ties may affect the level of cognitive conflict in the boardroom. A behavior theory of boards and governance will consider Organizations as multiple coalitions of actors. These actors may have conflicting interests and will achieve their goals through changing coalitions in the bargaining process within the corporation. In explaining decisions, a behavioral theory of boards and governance will focus on the political aspects of behavior (Zald, 1969), and also on the allocation and use of 
power in the top echelons of the Organization sand among alternative Coalitions of actors (Aguillera and Jackson, 2003). In this sense, future researches could analyse the Coalitions and use of power inside the board of directors to better explain the possible sources of conflicts. Finally, the interactions may take place between various board members, between the board members and TMT, or between the board members and the actors who are outside the firm. These interactions take place in various arenas and at various times (Huse, 2007) actors and their rational dynamics. Afterwards it is important to introduce and to consider these human elements in the analysis of board of directors and how the dynamic of conflicts influence board decision-making process.

\section{Research Methodology}

\subsection{Research Design}

The study utilized a descriptive cross sectional survey research design. Zikmund (2003) posits that surveys provide quick and accurate means of accessing information on a population at a single point in time. A descriptive crosssectional survey collects data to make inferences about a population of interest (universe) and have been described as snapshots of the populations from which researchers gather data. A survey assists the researcher to establish whether significant associations among variables exist at one point in time, depending on the resources available and the target population (Owen, 2002). A descriptive cross-sectional survey affords the opportunity to capture population's characteristics and test hypotheses quantitatively and qualitatively. Consequently, the researcher has no control on the variables thus cannot manipulate them making it inappropriate to use other research designs such as experimental research design (Kothari, 2003). A descriptive cross sectional survey research design was appropriate in this study because, the study aim to examine the moderating effect of Board Conflict Management Strategies on the relationship between corporate governance and organizational performance of the service state corporations in Kenya.

\subsection{Sampling Procedure and Sample Size}

The Explanatory survey method was adopted to obtain the relevant data which was used to determine the linkages between variables of the study, with the aim of testing the hypothesis formulated from the literature review. Primary data was used in the research study. State corporations that formed the sample was calculated using the sample formula (Fisher, Laing and Stoeckel (1985), as follows;

$$
\begin{gathered}
\mathrm{n}=\frac{Z^{2} p q}{e^{2}}=\frac{(1.96)^{2}(0.50)(0.5)}{(0.50)^{2}}=384 \\
\mathrm{n}_{\mathrm{f}}=\frac{n}{1+\frac{n}{N}}=\frac{384}{1+\frac{384}{187}}=125
\end{gathered}
$$

Where: $\mathrm{n}_{\mathrm{f}}=$ is the desired sample size (when the population is less than 10,000).

$\mathrm{N}=$ the Population (in this case 187 state corporations).

$\mathrm{n}=$ the desired sample size (if the target population is greater than 10,000)

$\mathrm{z}=$ the degree of confidence (in this case $95 \%$ confidence interval, $\alpha=1.96$ )

$\mathrm{p}=$ the proportion in the target population estimated to have characteristics being measured. $50 \%$ chosen as recommended by Fisher et al., (1985)

$\mathrm{e}=$ the level of statistical significance (set at 5\%).

Random sampling by making a complete list of all the elements in a population, assigning each a number and then drawing a set of random numbers which identifies $n$ members of the population to be sampled will be used to select sample elements.

The sample size was therefore comprises of 125 corporations with 375 respondents. Simple random sampling was then be used to select the sample of the 125 state corporations. From each state corporation of the sample size, three respondents was selected that included; Board chair, the $\mathrm{CEO}$ and any other board member.

\subsection{Data Collection Method and Procedures}

Firstly, the researcher obtained a letter from the university to enable her get permit from the council for science technology and innovation, which was then issue a research authorization permit. The questionnaires were then administered to each respondent physically, not in soft copies Two research Assistants preferably university students were employed to assist the researcher in dropping them to the corporations with instructions on how to fill them. Data used was collected from primary sources through use of self administered, structured questionnaires with a selfexplanatory cover letter. All the questionnaires were selfexplanatory. Questions will be accompanied by a 5-point interval rating scale that is the likert ranging from strongly agree to strongly disagree.

\subsection{Data Analysis}

A multiple regression model of Performance versus corporate governance was applied for examining the relationship between the two variables. Performance of the state corporations here is the dependent variable. The independent variables are the Board chair leadership, strategic involvement, the board knowledge, CEO-chair collaboration, Board Team production culture. Regression enables the identification of statistically significant relations between multiple variables. Specifically, it enables identification of the effects of several independent variables of a dependent variable, i.e. the extent to which variations in the dependent variables can be predicted by variations in the independent variables. Unlike factor analysis which is based on correlations. Inferential statistics such non-parametric test which include analysis of variance (ANOVA) was used to test the significance of the overall model at $95 \%$ level of 
significance. According to Mugenda (2008) analysis of variance is used because it makes use of the $\mathrm{F}-$ test in terms of sums of squares residual.

\section{Results and Discussion}

\subsection{Response Rate}

A total of 375 questionnaires were distributed to the selected respondents of State Corporation in Kenya. Out of the 375 questionnaires distributed, a total of 309 questionnaires were duly filled representing $82.4 \%$ response rate. This was an acceptable rate and could be attributed to the fact that the questionnaires were physically delivered to the respondents through drop and pick method. It is evident that $100 \%$ response rate was achieved to all state corporations with strategic functions. This was because majority of them are located within the capital city of Kenya.

\subsection{Assessment of Corporate Governance}

The study set out to establish the degree of corporate governance amongst state corporations in Kenya. The respondents had been asked to indicate the extent to which their state corporation boards focused on Leadership, Team production culture, strategic Involvement, CEO-Chair collaboration and member's knowledge/skills to represent corporate governance. Different sets of questions anchored on a five point Likert-type scale ranging from $1=$ Do not Know to 5= Strongly Agree were used to measure the five corporate governance. The state corporation aggregate score of board Leadership, board Team production culture, board strategic Involvement, board CEO-Chair collaboration and board member's knowledge/skills were computed for each as a simple average of the mean scores of the dimensions (sets of questions) responses.

In addition, standard error of mean (SE) was computed. Standard error of mean is a measure of reliability of the study results. It is equal to the standard deviation of the population divided by the square root of the sample size calculated as: $\mathrm{SE}=(\mathrm{SD})$ (of the population)/square root (n). Standard deviation shows how far the distribution is from the mean. A small standard error implies that most of the sample means will be near the center population means thus the sample mean has a good chance of being close to the population mean and a good estimator of the population mean. On the other hand, a large standard error illustrates that the given sample mean will be a poor estimator of the population mean (Harvill, 1991).

Corporate governance is seen as the process and structure used to direct and manage the business affairs of the company towards enhancing business prosperity and corporate accountability with the ultimate objective of realizing long-term shareholder value, whilst taking into account the interest of other stakeholders. Table 1 Summarizes the Individual Measures of Corporation Governance.
Table 1. Summary of Individual Measures of Corporation Governance.

\begin{tabular}{llll}
\hline Thematic Areas & N & Mean & SE \\
\hline Board Leadership & 303 & 4.67 & 0.048 \\
Board Team Production Culture & 303 & 4.63 & 0.058 \\
Board Strategic Involvement & 303 & 4.22 & 0.073 \\
Board CEO-Chair collaboration & 303 & 4.68 & 0.054 \\
Board members Knowledge and skills & 303 & 4.43 & 0.062 \\
Average Score & & 4.51 & 0.057 \\
\hline
\end{tabular}

The pertinent results in Table 1 show overall mean score for the Corporate govemance measures was 4.51, $\mathrm{SE}=0.057$. Board Leadership and Board CEO-Chair collaboration had the highest mean scores of 4.67 each. This implies that the board leadership is essential in discharge of board mandates. This implies that most of the board members are knowledgeable and experienced in leadership.

\subsection{Board Conflict Management Strategies}

Conflict is defined as a disagreement in judgment over the content of the tasks being performed, including differences in viewing points, ideas and opinions. Concept of cognitive conflict implies that the board members may have different opinions on important board issues. Each board member brings with them a different perspective on what is the best for the company and that they have different ways of arguing and reasoning (Huse, 2007). The Board Conflict Management Strategies process encompasses a wide range of activities including communication, problem solving, dealing with emotion and understanding positions. The study identified three main strategies of resolving a conflict within the board namely; negotiation, mediation and arbitration.

Table 2. Measures of Board Conflict Management Strategy Concept.

\begin{tabular}{llll}
\hline Board Conflict Management & N & Mean & S.E \\
Strategy Concept & 303 & 4.60 & 0.035 \\
\hline Negotiation & 303 & 3.72 & 0.053 \\
Mediation & 303 & 3.74 & 0.056 \\
Arbitration & & 4.02 & 0.048 \\
Average score & & \\
\hline
\end{tabular}

\subsubsection{Negotiation}

The study sought to establish effectiveness of negotiation as a strategy of resolving conflict by the board in the state corporation. A board of director's, function as a negotiation forum where directors are searching for a compromise among a set of diverging interests. A closer examination of both the interests represented in the boards of the directors' selfinterest may further improve understanding of the institutional and ownership context affecting the role of the board and its functioning.

\subsubsection{Mediation}

The study sought to establish effectiveness of mediation by the board members in managing conflict in relation to the organization performance. It was noted that, generally mediation was not the most effective way of managing a conflict because majority of the respondents had a mean score of approximately 3 (Disagree). There may also exist various ways of arguing or reasoning among the board 
members.

\subsubsection{Arbitration}

The study sought to identify effectiveness of arbitration as a strategy of resolving conflict by the board. The overall mean score of 3.74 (agree) shows that majority of the respondents were in the view that arbitration conflict management concept is slightly effective in resolving conflict. The arbitrator listens to presentations made by both sides of the Board members while setting Board conflicts. This will contribute positively to achieving performance and Transparency in the boardroom and the organization of State Corporation.

\subsection{Organization Performance}

Organization performance refers to an analysis of State Corporation performance as compared to goals and objectives, within corporate organizations. There are three primary outcomes analyzed financial performance, market performance and customer/shareholder value performance. Effective Boards add value and contribute to the direction and performance of the Organization by their involvement in strategic decision making (forbes and Milliken 1999, judge and zeithamil 1992). The study considered customer satisfaction as a way of examining organization performance. Customer satisfaction includes measures such as customer expectation of the service delivery, actual delivery of the customer experience, and expectations that are either exceeded or unmet. Positive disconfirmation results when customer expectations are met and exceeded, while a negative disconfirmation results when customer experience is poorer than expected (Javalgi, Whipple and Ghosh, 2005). Positive customer outcomes such as customer satisfaction have been linked with the market-oriented corporations. Market-oriented state corporates are well-positioned to anticipate customer needs and wants and offer goods and services that may satisfy the current and unmet needs. Customer satisfaction represents the effectiveness of the firm in delivering value to its target customers. Table 4 summarizes the level of customer satisfaction as perceived by Board members.

Table 3. Customer Satisfaction.

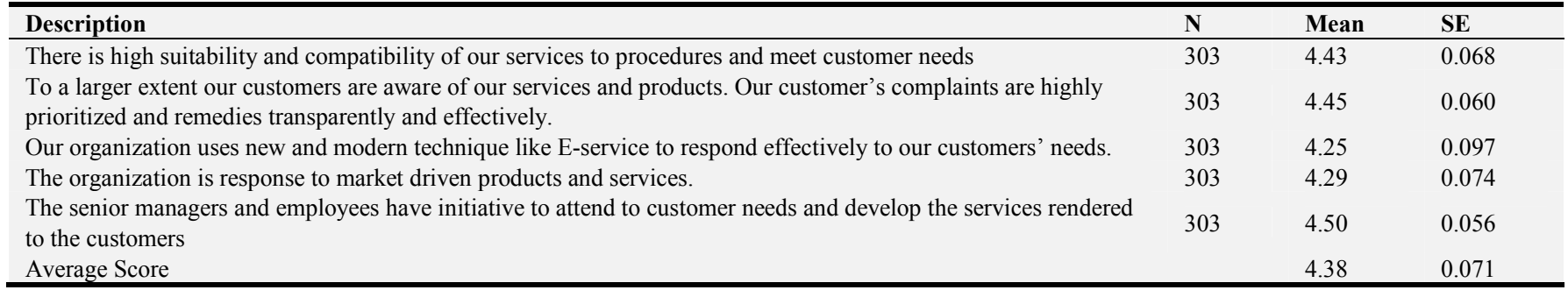

The results in Table 4 show that the average scores for customer satisfaction was 4.38, $\mathrm{SE}=.071$. For customer satisfaction to be high, promises and expectations must be met. This implies that customer satisfaction is an important measure of organization performance. As far as the individual responses are concerned, the senior managers and employees have initiative to attend to customer needs and develop the services rendered to the customers had the highest score (mean score $=4.50, \mathrm{SE}=.056$ ). Loyal customers will not only provide most of the corporate profits but will cover the losses incurred in dealing with less loyal customers.

\subsection{Moderating Effect of Board Conflict Management Strategies on the Relationship Between Corporate Governance and Organization Performance}

This study sought to assess the moderating effect of Board Conflict Management Strategies on the relationship between corporate governance and organization performance. To assess the moderating effect, hypothesis given below was formulated;

Ho: The relationship between corporate governance (Board Leadership) and organization performance of the state corporations is statistically significant moderated by Board Conflict Management Strategies in Kenya.

The moderating effect was computed using the method proposed by Baron and Kenny (1986). This involved testing the main effects of the independent variable (corporate governance) and moderator (Board Conflict Management Strategy) on the dependent variable (organization performance) and the interaction between corporate governance and the Board Conflict Management Strategy. The significance of the independent variable and the moderator variable is not particularly relevant in determining moderation. Moderation is assumed to take place if the interaction between the Corporate governance and Board Conflict Management Strategy is significant. To create an interaction term, the corporate governance and Board Conflict Management Strategy measures were first centered and a single item indicator representing the product of the two measures calculated. The creation of a new variable by multiplying the scores of corporate governance and Board Conflict Management Strategy created a multi-collinearity problem. To address the multi-collinearity problem, which can affect the estimation of the regression coefficients for the main effects, the two factors were converted to standardized (Z) score that have mean zero and standard deviation one. The two standardized variables were then multiplied to create the interaction variable. This is consistent with previous studies that have used $\mathrm{Z}$ scores when testing for the moderating effect (Slater and Narver, 1994; Kumar et al. 1998). The relevant analytical results are portrayed in Table 5 
Table 4. Regression Results of Board Leadership and Organization Performance moderated by Board Conflict Management Strategies.

(a) The Goodness of Fit

\begin{tabular}{lllll}
\hline Model & R & R Square & Adjusted R Square & Std. Error of the Estimate \\
\hline 1 & $.374^{\mathrm{a}}$ & .140 & .131 & .03231 \\
2 & $.480^{\mathrm{b}}$ & .231 & .215 & .03254 \\
3 & $.547^{\mathrm{c}}$ & .299 & .277 & .03035 \\
\hline
\end{tabular}

(b) The Overall Significance

\begin{tabular}{|c|c|c|c|c|c|c|}
\hline Model & & Sum of Squares & df & Mean Square & $\mathbf{F}$ & Sig. \\
\hline \multirow[t]{3}{*}{1} & Regression & 1.867 & 1 & 1.867 & 15.936 & $.000^{\mathrm{a}}$ \\
\hline & Residual & 35.334 & 302 & 0.117 & & \\
\hline & Total & 37.201 & 303 & & & \\
\hline \multirow[t]{3}{*}{2} & Regression & 3.08 & 2 & 1.54 & 14.545 & $.000^{\mathrm{b}}$ \\
\hline & Residual & 31.906 & 301 & 0.106 & & \\
\hline & Total & 34.986 & 303 & & & \\
\hline \multirow[t]{3}{*}{3} & Regression & 3.873 & 3 & 1.291 & 13.666 & $.000^{\mathrm{c}}$ \\
\hline & Residual & 28.2 & 300 & 0.094 & & \\
\hline & Total & 32.073 & 303 & & & \\
\hline
\end{tabular}

(c) The Individual Significance

\begin{tabular}{|c|c|c|c|c|c|c|}
\hline \multirow{2}{*}{\multicolumn{2}{|c|}{ Model }} & \multicolumn{2}{|c|}{ Unstandardized Coefficients } & \multirow{2}{*}{$\begin{array}{l}\text { Standardized Coefficients } \\
\text { Beta }\end{array}$} & \multirow{3}{*}{$\begin{array}{l}\mathbf{t} \\
6.315\end{array}$} & \multirow{3}{*}{$\begin{array}{c}\text { Sig. } \\
.000\end{array}$} \\
\hline & & \multirow{2}{*}{$\begin{array}{l}\text { B } \\
2.762\end{array}$} & \multirow{2}{*}{$\begin{array}{l}\text { Std. Error } \\
.437\end{array}$} & & & \\
\hline & (Constant) & & & & & \\
\hline 1 & Corporate governance & .372 & .093 & .374 & 3.992 & .000 \\
\hline & (Constant) & 1.832 & .498 & & 3.675 & .000 \\
\hline 2 & Corporate governance & .371 & .088 & .374 & 4.195 & .000 \\
\hline & Board Conflict Management Strategies & .232 & .069 & .301 & 3.385 & .001 \\
\hline & (Constant) & -6.864 & 4.185 & & -1.640 & .104 \\
\hline & Board Leadership & 2.256 & .881 & 2.306 & 2.561 & .012 \\
\hline 3 & Board Conflict Management Strategies & 2.389 & 1.052 & 3.148 & 2.270 & .025 \\
\hline & $\begin{array}{l}\text { Product of Corporate governance and Board Conflict } \\
\text { Management Strategies }\end{array}$ & -1.843 & .886 & -3.437 & -2.080 & .040 \\
\hline
\end{tabular}

1. Predictors: (Constant), Corporate governance

2. Predictors: (Constant), Corporate governance, Board Conflict Management Strategies

3. Predictors: (Constant), Corporate governance, Board Conflict Management Strategies, Corporate governance *Board Conflict Management Strategies

4. Dependent Variable: Organization Performance

The results in Table 5 show the Corporate governance and Board Conflict Management Strategies variables explained $23.1 \%$ of the variation in the organization performance $\left(R^{2}=0.231\right)$. Under change statistics, the results reveal that $R^{2}$ change increased by $7 \%$ from 0.231 to $0.299 \quad\left(\mathrm{R}^{2}\right.$ change $=0.068)$ when the interaction variable was added. Moreover, the change was statistically significant at $5 \%(\mathrm{P}-$ value $=0.040$ ). The results show a statistically significant relationship between Corporate governance and Board Conflict Management Strategies variables and interaction $(\mathrm{F}=13.666, \mathrm{P}$-value $=0.000)$. The results in model 3 Table 5 show statistically significant regression coefficients for Corporate governance (Coefficient $=2.256, P$-value $=0.012$ ) indicating that there is a linear dependence of the organization performance and Corporate governance. Indeed, there is a statistically significant relationship between the Board Conflict Management Strategies and organization performance $($ Coefficient $=2.389, \mathrm{P}$-value $=0.025$ ). From the current research findings, the multiple regression equation used to estimate the moderating effect of Board Conflict Management Strategies on the board leadership and organization performance relationship is stated as follows:

\section{$\mathrm{Y}=2.256 \mathrm{X}+2.389 \mathrm{M}-1.843 \mathrm{~K}$}

Where $\mathrm{Y}=$ Organization Performance; $\mathrm{X}=$ Corporate governance; $\mathrm{M}=$ Board Conflict Management Strategies: $\mathrm{K}=$ Product of Corporate governance and Board Conflict Management Strategies

The hypothesis that the relationship between corporate governance and organization performance of the state corporations is statistically significant moderated by Board Conflict Management Strategy is supported by the current study.

\section{Conclusion and Recommendation}

The study revealed that the relationship between corporate governance (board leadership) and organization performance of the state corporations is statistically significant moderated by Board Conflict Management Strategies. According to Carter and Lorsch, 2004; Leblanc and Gillies (2005) argue that at the heart of good corporate governance is not board structure (which receives a lot of attention in the current regulations), but instead board process especially consideration of how board members work together as a group and the competencies and behaviors both at the board level and the 
level of individual directors. The study revealed that board conflict management strategies are key factor in resolving conflict within the board and in the State Corporation. Once a conflict is resolved, the study found that organization performance changes by $7 \%$. The study, recommend application of Arbitration, Negotiation and Mediation strategies in resolving a conflict in the state corporation for the effective and efficient services to the public.

\section{Acknowledgement}

Special thanks go to my supervisors Professor Thomas Cheruiyot and Dr. Joyce Komen for their tireless efforts in guidance, encouragement, patience and understanding. I acknowledge their skills and insights into the subject of the study. My Special gratitude goes to the NHIF Management for providing an enabling environment during the whole period of the study.

\section{References}

[1] Anderson, R. C. and Reeb, D. M. (2004), Board composition balancing family influence in S and P 500 firms. 209/ Administrative science quarterly, 49 (2004): 209-237.

[2] Balakrishnan, S. (1996), Benefits of customer and competitive orientations in industrial markets. Industrial Marketing Management, 25 (7), 257-269.

[3] Barnhart, S. W. and Rosenstein, S. (1998), Board composition, managerial ownership and firm performance: An empirical analysis. The financial review 33: 1-16.

[4] Baron, R. M., \& Kenny, D. A. (1986), The moderatormediator variable distinction in social psychological research: Conceptual, strategic and statistical considerations. Journal of Personality and Social Psychology, 51, 1173-82.

[5] Baysinger, B. D. and Butler, H. N. (1995), corporate governance and the board of directors: Performance effects of changes in board composition Journal of Law, Economics and Organization, 1, 101-124.

[6] Baysinger, B. D. and Hoskisson, R. E. (1990), the composition of boards of directors and strategic control effects on corporate strategy, Academy of management review 15 (1): 72-87.

[7] Bonn, I. and Fisher, J. (2005), corporate governance and business ethics: Insights from the strategic planning experience. Corporate governance volume 13 .

[8] Bosch, H. (1995). Corporate practices and conduct. Melbourne: FT Pitman.

[9] Business round table (2005). Principles of corporate governance, a white paper by, www.businessroundtable.org/,January, 8,2007.

[10] Byrd, J. W. and Hickman, K. A. (1992). Do outside directors monitor managers? Evidence from tender offer bids. Journal of financial economics 32: 195-221.

[11] Chaganti, R. S., Mahajan, V. and Sharma, S. (1985), Corporate board size, composition and corporate failures in retailing industry. Journal of management studies 22: 400-417.

[12] Chiang, H. (2005), an empirical study of corporate governance and corporate performance. The journal of American academy of business, Cambridge 95-110.

[13] Chung, K. H. and Pruitt, S. W. (1994), a simple approximation of Tobin's Q, Financial management, 23 (3), 70-74.

[14] Clark, W. and Demirag, I. (2002), Enron: The failure of corporate governance, Greenleaf Publishing.

[15] Cooper, D. R., \& Schindler, P. S. (2003). Business Research Methods (8th ed.). New Delhi: Tata McGraw-Hill Publishing Limited.

[16] Cotter, J. F., Shivdasani, A. and Zenner, M. (1997), Do independent directors enhance target shareholder wealth during tender offer? Journal of financial economics 43: 195218.

[17] Daily, C. M. and Dalton, D. R. (1993), Board of directors leadership and structure: Control and performance implications, Entrepreneurship: Theory and practice, 7, 65-82.

[18] Daily, C. M. and Dalton, D. R. (1994), Bankruptcy and corporate governance: The impact of board composition and structure, Academy management Journal 37: 1603-1617.

[19] Dalton, D. R., Daily, C. M., Ellstrand, A. E. and Johnson, J. L. (1999), Number of directors and financial performance: A meta-analysis, Alacademy of management Journal 42 (6): 674-686.

[20] Davidson, W. N., Pilger, T and Szakmary, A. (1998), Golden parachutes, board and committee composition and shareholder wealth, The financial review 33: 17-32.

[21] Davis, J., Donaldson, L. and Schoorman, D. (1997), toward a stewardship theory of management, Academy of management review 1997, Vol. 22 No. 1, 20-47.

[22] Dicke, L. A. And Ott, S. (2002), A test: Can stewardship theory serve as a second conceptual foundation for accountability methods in contracted human services? International Journal of public administration, 25 (4), 463-487.

[23] Donaldson, L. \& Davis, j, (1991). Stewardship Theory or Agency Theory; CEO Governance and Shareholder Returns. Academy of Management Review, Vol 20, No. 1 pp 65.

[24] Donaldson, L. and Davis, J. H. (1991), Stewardship theory or agency theory: CEO governance and shareholder returns, Australian Journal of management. 16 (1), pp 49-64.

[25] Eisenberg, T., Sundgren, S, and Wells, M. T. (1998), larger board size and decreasing firm value in small firms, Journal of financial economics 48: 35-54.

[26] Finkelstein, S. and Aveni, R. A. (1994), CEO duality is double edged sword: How boards of directors balance entrenchment avoidance and unity command, Academy of management Journal 37, 1079-1108.

[27] Fisher, A. A., Laing, J., \& Stoeckel, J. (1985). Guidelines for Overcoming Design Problems in Family Planning Operations Research. Studies in Family Planning, 16 (2).

[28] Forbes, D. P. and Milliken, F. (1999), Cognition and corporate governance: Understanding board of directors as strategic decision-making groups, Academy of management review, 3, 489-505. 
[29] Gathura, A. N., (2007). Corporate governance structure and performance of manufacturing Firms.

[30] Gatignon, H., \& Xuereb, J. M. (1997), Strategic orientation of the firm and new product performance. Journal of Marketing Research, 34 (1), 77-90.

[31] Gitari J. M. (2008). Corporate governance and the financial performance of state corporations: the case of new Kenya cooperative creameries. Unpublished MBA project University of Nairobi.

[32] Gladstein, D. (1984), a model of task group effectiveness, Administrative science quarterly, 29: 499-517.

[33] Golden, B. R. and Zajac, E. J. (2001), when will boards influence strategy? Inclination $\mathrm{x}$ power $=$ strategic change, Strategic management Journal 22: 1087-1111.

[34] Hair, J. F., Anderson, R. E., Tatham, R. L., \& Black, W. C. (1998). Multivariate Data Analysis with Readings (5th ed.). Englewood Cliffs, NJ: Prentice Hall.

[35] Harvill, L. M. (1991), An NCME instructional module on standard error of Measurement. ITEMS, (Summer), 33-41.

[36] Holderness, C. G and Sheehan, D. P. (1998), the role of majority shareholders in publicly held corporations. Journal of financial economics 20: 317-346.

[37] Javalgi, R. G., Whipple, T. W., \& Ghosh, A. K. (2005), Market orientation, strategic flexibility, and performance: Implications for services providers. Journal of Services Marketing, 19 (4), 212-221.

[38] Jensen M (2001) Value Maximization, stakeholder Theory and the Corporate Objective Function. European Financial Management 7, 297-317.

[39] Jensen, $M$ and Meckling. W (1976). Theory of the firm: Managerial Behavior, Agency Costs, and Ownership Structure. Journal of Management, Vol. 22 No 3, pp. 409-438.

[40] Jensen, M. C. and Meckling, W. H. (1976), Theory of the firm: Managerial behavior, agency costs and ownership structure. Journal of financial economics, 3, 305-360.
[41] Kang, J. K. and Shivdasani, A. (1995), Firm performance, corporate governance and top executive turnover in Japan. Journal of financial economics 38: 29-58.

[42] Kiel, G. and Nicholson, G. (2003), Board composition and corporate performance: How the Australian experience informs contrasting. Corporate governance Volume 11 No. 3.

[43] Klein, A. (1998), Firm performance and board committee structure. Journal of law and economics: 41 (1): 275-303.

[44] Kothari, C. R. (2003). Research Methodology: Methods and Techniques. New Delhi New Age Int. Publishers.

[45] Lorsch, J. W. and Zelleke, A. (2005), should the CEO be Chairman? MIT Sloan management review, Vol. 46 (2), 71-74.

[46] Malhotra, N. K., \& Dash, S, (2011), Marketing Research an Applied Orientation. New Delhi: Pearson.

[47] Mugenda, M. O. \& Mugenda (2003). Research Methods: Qualitative and Quantitative Approaches, Acts Press, Nairobi.

[48] Owen, L. (2002). Introduction to Survey Research Design. SRL Fall 2002 Seminar Series: http://www.srl.uic.edu

[49] Private sector initiative report (1998). Principles of corporate governance in Kenya and a sample code of best practice. Kenya Private sector corporate governance trust.

[50] Rechner P. L. \& Dalton, D. R. (1991), CEO duality and Organizational performance; a longitudinalanalysis. Strategic Management journal 12, 155-160.

[51] Slater, S. F., \& Narver J. C. (1994b), Market orientation, customer value and superior performance. Business Horizon, 37 (2), 22-28.

[52] State Corporations Advisory Circular (2010). Office of the President, Government Printing Press, Nairobi.

[53] Sundarom, A. K, \&Yamach, C. (1999). The Corporate Objective Revisited.

[54] Zikmund, W. G. (2003). Exploring Marketing Research (7th ed.). USA: Thomson, South Western. 